\title{
A GAELIC SCHOLAR'S APPROACHES TO RECORDING AND TABULATION IN EARLY EIGHTEENTH-CENTURY DUBLIN
}

\author{
LIAM MAC MATHÚNA
}

\section{Introduction}

Seán Ó Neachtain (c.1640-1729) and his son Tadhg (1671-c.1752) were at the centre of a network of about thirty Irish language scholars which existed in Dublin in the early eighteenth century. The modernising tendencies demonstrated by Tadhg Ó Neachtain in his manuscripts continue to attract considerable academic attention. The poem beginning Sloinfead scothadh na Gaoidhilge grinn / dá raibhe rém rae $i$ Nduibhlinn, composed by him in $1728 / 29$, celebrates some twenty-six scholars connected with the city at the time, while six of his manuscripts contain commonplace entries and incorporate many contemporary newspaper accounts of events in Ireland and abroad, both in Irish translation and in the original English, alongside more familiar material associated with the Gaelic literary tradition. This paper sees the versified catalogue of scholars in Dublin and the manuscript interaction with news from the public sphere in Dublin and abroad as relating to new understandings of information, coupled with the urge to record, tabulate, interpret and interact with contemporary events. Among other sources which will be considered are Tadhg's list of family events (births, deaths) (in Irish), an inventory of books and manuscripts lent out (in English) and poems celebrating his father's creative works and listing the teachers who provided his son Peadar's schooling (both in Irish). Finally, an attempt will be made to situate Tadhg Ó Neachtain's interaction with information and knowledge alongside other aspects of the Gaelic tradition.

\section{Linguistic background}

I would like to begin by making just brief summary reference to the linguistic background of eighteenth-century Dublin. Founded as a settlement by the Vikings in 841 A.D., it is often assumed both in Ireland and abroad that Dublin was never an Irish-speaking city. This may be true in the strict sense that the city was probably never predominantly Irish-speaking, but it is nonetheless subject to important reservations. Firstly, the general Dublin area was comparatively well populated before the Vikings settled there, and Irish would have been the only language spoken prior to the arrival of the Norse in Ireland in 795 A.D. A monastery was already founded by the black pool which eventually gave the city its current English name of Dublin, originally a compound based on the Irish elements $d u b$, dubh 'black' and linn 'pool'. 
This pool is believed to have been situated where the circular garden beside the Chester Beatty Library in Dublin Castle is to be found today. Most scholars continue to locate the ford crossing which gave the city its current Irish name, Baile Átha Cliath, at Queen Street bridge. Baile Átha Cliath is based on the Irish words baile 'town' + áth 'ford' (in the genitive singular) + cliath 'hurdle' (in the genitive plural), that is 'the town of the ford of the hurdles'. Before $c .1368$ the town was known simply as Áth Cliath, literally 'the ford of the hurdles'. While English would have replaced Old Norse and Irish as the dominant language of Dublin following its capture by the Normans in 1170, we have continuing evidence for the use of Irish by a minority of inhabitants down through the sixteenth and seventeenth centuries.

At any rate, although the conquest of Ireland by England was complete by the beginning of the eighteenth century, and although the English language was used virtually exclusively in public affairs, there is extensive evidence of a lively circle of Irish-speaking scholars in the city of Dublin at that time. At the centre of this circle were Seán Ó Neachtain and his son Tadhg, both schoolteachers, scholars and scribes. Seán and Tadhg were men of wide interests. Tadhg wrote a world geography textbook, Eólas ar an Domhan, in the 1720s. This is in the form of a dialogue between himself and his father. The 1720s was also a period when Tadhg was busily engaged in translating news items from the Dublin newspapers into Irish, and including them as commonplace entries in a number of his manuscripts. Tadhg was very much in the Skibbereen Eagle mould and kept a close eye on the world. Be it the state of health of 76-year-old Pope Benedict XIII in Rome in 1725 (RIA 24 P 41: 221), a great storm in Bengal in 1707 (NLI G 135: 19) or an earthquake in Lima (1746/47; NLI G 135: 169), Tadhg was on the case.

As noted by the author in a previous article (Mac Mathúna 2010), Breandán Ó Buachalla (1996: 380-1) has shown that one news item has been translated quite closely from Faulkner's Dublin Journal. This is an account of an audience granted on 14 November 1725 by Pope Benedict to the Pretender (don treas Seamus righ Sacson, 'to James the third, king of the English') who was accompanied by his son (oighre an tSeamuis, 'James's heir') and may be quoted again here:

His Holiness continues constant in his devotion, watchings and fastings and on all occasions seems sensible of the nothingness of this world; and tho' the clergy here, as well as in other parts, are wishing for a new conclave, yet his Holiness is in as good a state of health as can be expected for one who is upwards of 76 years of age... The Chevalier de St. George, his spouse and eldest son, had lately an audience of the Pope...

(Faulkner's Dublin Journal: 18.12.1725) 
Áth Cliath Dia Sathurn Dec. 18. 1725

Nuadhuigheacht. Róimh Nov. 14. Ní thochtann an Pápa Benedict oidhche nó lá ó throsga crádhbhadh nó urnuighthe acht ag gnáithbhreathnughadh dísbeagadh neamharthannuidh an tsaoghuil si; 7 gi beith dó corra ${ }_{7} 76$ bliadhuin daois tug éisteacht bháidheamhuil don treas Séamus rígh Sacson bhí ar deoruigheacht san Róimh fon amso agus do theagasg é re briathraibh caoin agá aisge bheith foighideach a nannródhaibh, agus na dhiaighsin glacan oighre an tSéamuis suas idir a ghéaga re áilgeas cumainn agá bheannughadh agus agá rádh ris: "Go ndéana an tigearna coidheagna codhchródha re hathair tú agus go dtugadh rialughadh cumann dísleacht agus cneastach do shinnsear dhuit" .. . Seorsa Falcnar an clodhuighthe (RIA 24 P 41: 221).

Other foreign events considered worthy of mention in the same manuscript and which have a Slavic connection are the translation of the King of Poland's farewell address to his daughter in 1725. This is headed Comhairla Stanislaus righ Poland da inghean Bainriaghan Francg ag ceillebhradh dóibh re ar oile Aug. 1725, 'The advice of Stanislaus, king of Poland, to his daughter, queen of France, as they take leave of each other Aug. 1725', and the translation of a news item describing the visit of a Persian plenipotentiary to the court of Peter the Great (Mac Mathúna 2010: 36-7).

As father and son, Seán and Tadhg Ó Neachtain were particularly close. They have left a valuable literary legacy of some thirty manuscripts, which shed a great deal of light on the affairs of the time, and more particularly on the nature of their relationships with their families and their circle of scholarly friends in Dublin. This wider group is believed to have penned over a hundred manuscripts in all. This paper centres on just one aspect of the Ó Neachtains' scribal activity, that of listing, recording and tabulating. It may seem a relatively minor matter, at first, but in fact I believe that its role in their work is indicative, in Tadhg's case especially, of a modern approach to the world. Together with his keen interest in current affairs and foreign lands, it underlines the fact that Tadhg was looking at the world in new ways: his love of lists can be set alongside his sensibility and urbanity, as yet another indication of the influence of modernity on the Ó Neachtains and their circle.

\section{Listing and recording}

The urge to record and bestow permanence on important information of personal, political and commercial interest gave impetus to the early stages of writing, which was itself preceded by memorised oral recording of genealogies, laws and the like. Metrical regularity, rhythm and rhetorical devices would all have aided the memory of composer, reciter and listeners in maintaining accuracy and continuity over time in oral societies. But, as well as being a mnemonic device, rhetoric may hold aesthetic attractions, whether it 
be in litanies of the saints, sea-area weather forecasts or football league results. As Umberto Eco points out succinctly in his 2009 volume, The Infinity of Lists: From Homer to Joyce, "there are lists and lists": “... we must make an important distinction, and that is between practical or 'pragmatic' and 'poetic' lists (and by the latter term we mean any artistic end for which the list was proposed and whatever art form is used to express it)" (Eco 2009: 113).

Eco maintains that practical lists have a purely referential function: they refer to objects in the outside world and have the practical purpose of naming and listing them. They comply with a contextual pressure in that they form a set (id., 2009: 113-4). Poetic lists, on the other hand frequently combine the allure of sound as well as enumeration (id., 2009: 117-8). But the distinction is probably really one of degree rather than of essence. Nonetheless, the rise of print facilitated greater use of referential, practical listing, and that is probably where much of the motivation for Tadhg O Neachtain's innovation with regard to contemporary lists use is to be found.

The second decade of the twentieth century saw the publication of three works which propelled Seán Ó Neachtain and his son Tadhg somewhat belatedly into the world of the Irish language revival, almost twenty years after the founding of the Gaelic League in Dublin in July 1893, with Douglas Hyde as its first President, and Eoin MacNeill as its first Secretary. The first of these publications was Filidheacht Sheagháin Ui Neachtain (1911), a slim anthology of just thirty-five pages, which contained some twelve poems composed by Seán Ó Neachtain, with rather minimal editing by Úna Ní Fhaircheallaigh, lecturer in Modern Irish in University College Dublin, and then a colleague of Douglas Hyde, who had been appointed the first Professor of Modern Irish. However, Ní Fhaircheallaigh's volume was destined to have a certain lasting impact, for the very first poem in the collection shows Seán at his creative best, and extracts from it have frequently been included in later anthologies of Irish verse. In this composition, beginning Rachainn fó'n gcoill leat, Seán seeks to woo his future wife Úna Ní Bhroin by proposing that they both escape to an idyllic countryside. ${ }^{1}$ This poem has thirty-six stanzas and commences as follows:

Rachainn fó'n gcoill leat, A mhaighdean na n-ór-fholt, 'Féachain ar éanlaith, 'S ag éisteacht a gceól-ghob.

(Ní Fhaircheallaigh 1911: 3-9)

\footnotetext{
${ }^{1}$ Ironically, the theme of escaping to an idyllic countryside actually serves to underscore the reality of an urban milieu.
} 
I would go to the wood with you, O maiden of the golden tresses,

Looking at the birds, and listening to their beak-music. ${ }^{2}$

What is of interest here is the fact that, in his efforts to conjure up the attractions of going down to the woods, Seán proceeds to recount and list the pleasures of listening to the many birds of the wood, including the thrush and the blackbird, the wren, the female blackbird, the lark, the snipe, the sparrow, the dove, the wood-quest, the starling, the field-fare, the cuckoo, the quail, the corncrake, the curlew, the snipe, the robin, the drake, the duck, the crane, the bittern, [the bee], the peacock, the partridge, the turkey-cock, the gander, the (red) grouse, the pheasant, the wood-pecker, the black partridge hen and cock, the nightingale and the swan. They occur as follows in the original Irish:

ag an smólach
londuibh
ag an dreólán
ag céarsach
an uiseog
an meantán
gealbhan
cuilm
fearáin
an truideóg
an sacán
cuach
gearr ghuirt
traona
an crotach
an naosga
spideóg
márdail
lachain
an chorrmhónadh
punnán léana
beich
péacóg
paitrisg
an coileach francach
an gandal
cearc fhraoich
feasain

\footnotetext{
${ }^{2}$ Translations are by the author, unless otherwise stated.
} 


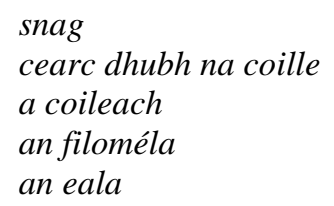

The sea-birds will also come to greet them, namely, the eagle, the sea-gull, the jackdaw, the wood-cock, the eagle, the wren and the mole. Again, in Irish, these are:
iolar
faoileann
cabhóg
corr ghrian
an coileach feadha
an $t$-iolar
dreoilín
an caochán cuilinn

Then Seán sums up his case, saying that Úna will have all she could wish for:

Biaidh an uile ní frat,

Dár mian leat á chathaigh,

'S go deóidh na díle,

Ní sgaoilfe mo pháirt leat.

Everything will be beside you,

of whatever you want, my love,

and until the final flood

My love will last.

He then concludes with a final list, assuring Una that they will be joined by many animals, the badger, the wolf, the fox, the stag, the rabbit, the weasel, the squirrel, [the fishes] and the otter. In Irish, they are rendered as follows:
bruic
faolchuin
sionnaigh
buic
an coinín
iosóg
an iara
éisg
dobhráin 
Úna was obviously impressed, for she responds eloquently in Seán's poem, passionately assuring him of her love:

Mo bhéal ar do bheól-sa,

Mo dhóid ar do chliabh-sa,

Ag éisteacht do ghlóir ghlic,

Do thóigfeadh mo phianta.

Racha mé féin leat

Gan éaradh, go súgach,

'Féachain ${ }_{7}$ ag éisteacht

Na n-éan sin ag súgradh.

(Ní Fhaircheallaigh 1911: 3-9)

My mouth on your mouth.

My hand on your chest,

Listening to your clever voice,

Which would take away my pain.

I will go with you

Without refusing, merrily,

Looking and listening

To those birds at play.

Following the death of Úna in 1706, Seán composed two poems expressing his grief. Having praised her beauty in the opening verse of the second lament, beginning Thug mé searc mo chléibh 's mo ghrádh, he proceeds to describe her qualities in the second stanza:

Mine méin 7 tréithe i nglóir

Caoine, séimhe is béasa cóir,

Féile, fairsinge, chleacht 'n-a dáil

Mé n-a heasbhaidh, 's creachta 'tá.

Och! Ochón! ó d'éag mo stór,

Is truagh mé ar éigin ' $m$ ' éin-fhear bheó.

(Ní Fhaircheallaigh 1911: 12)

Gentleness in disposition and accomplishment in speech

Gentleness, softness and fair manners,

Generosity, open-handedness, she practised when met

My wanting her, is a ruined state.

O! Alas! as a result of your death, my love,

I am an object of pity, a [single] man barely alive. 
In this poem, then, one sees, that rather than provide a longer, more exhaustive, list, Seán has chosen to cite a few of his deceased wife's most attractive personal characteristics.

\section{Code-mixing}

The year 1918 saw the publication of Seán Ó Neachtain's most famous and enduring prose work, entitled Stair Éamuinn Uí Chléire ('The History of Éamonn Ó Cléirigh'), which he composed about the years 1710-14. It was edited by a name-sake, Eoghan Ó Neachtain, a native speaker of Irish from Cois Fharraige, Co. Galway (Ó Neachtain 1918). The story tells of Éamonn Ó Cléirigh's struggle to overcome his addiction to alcohol, and is usually held to contain strong parallels to Seán's own life experiences. If so, it is an allegorical autobiography in which the hero eventually gets the better of the demon drink with the aid of a priest friend called Mac Aodhagáin, thus winning the hand of his wife Úna. This linguistically exuberant text includes a number of extended passages in English, which form the basis of elaborate Irish/English code-mixing and puns which have a Myles na gCopaleen ring to them. Understood originally by scholars to belong to the romance genre, its innovative features so impressed Cathal Ó Háinle that in 1978 he hailed it as a harbinger of the novel genre in Irish (Ó Háinle 1978; see also Ó Háinle 2004). The nature and role of the various passages in English have given rise to lively debate. One example will have to suffice here to give a flavour of this aspect of the work. It is the first of the passages in English and occurs some time into the tale, when the (anti-)hero Éamonn meets a young boy who felt compelled to speak in English only and is said to have laboured under glas Béarla or 'an English lock'. Names play a prominent part in the cross-lingual exercise in non-communication. When Éamonn came to the boy's house, he enquired where bean an ti 'the woman of the house' was and the boy replied: "She is go 'pon market". The boy shows that he is engaged in translation from the Irish, when Éamonn fails to realise in one case that the English offered represented a proper noun or name:

But who is the husband of the woman that uses to be in the house? ar Éamonn.

Mandark from two swan, ar eisean.

Arú, ar Éamonn, what is it in Irish?

Feardorcha Ó Dála, ar eisean. (Ó Neachtain 1918: 31)

But who is the husband of the woman that uses to be in the house? said Éamonn.

Mandark from two swan, said he.

Now, said Éamonn, what is it in Irish?

Feardorcha Ó Dála, said he. 
The Irish personal name Feardorcha may be deconstructed as fear 'man' + dorcha 'dark', which are duly rendered into English, according to the normal word-order of Irish, in which the adjective follows the noun, giving the English Mandark. The additional phrase in English, from two swan, indicates that the Irish surname $O$ Dála was understood as comprising the preposition $o$ 'from' and Dála, a compound based on the Irish $d(h) a ́$ 'two' + eala 'swan'. The Irish practice of using the singular after the number 'two' was adhered to in the English version. ${ }^{3}$

\section{Circle of scholars}

While these two very different works of poetry and prose gave some indication of the wide creative range traversed by Seán Ó Neachtain, it was actually the appearance in 1913 of an unusual poem by Seán's son Tadhg, edited by Prof. T. F. O'Rahilly, which established the reputation of the Ó Neachtains as a literary and scholarly force to be reckoned with in early eighteenth-century Dublin (O'Rahilly 1912-13: 156-162, 302-303). O'Rahilly foregrounded the concept of a 'circle', already to be found in the poem itself, and this has proved influential in shaping the parameters of subsequent research. This poem of just 104 lines, evidently composed in 1728, begins

\section{Sloinfead scothadh na Gaoidhilge grinn dá raibhe rém rae a Nduibhlinn}

(O’Rahilly 1912-13: 156)

I will name the flower of the scholars of the clear Irish who were in Dublin in my time

The regional background of most of the 26 scholars named in this poem is known. Six were natives of Connacht, five came from Munster, one was from Ulster and ten were from Leinster. Of those hailing from Leinster, two were from Dublin itself (Uilliam Ó Loingsigh and Risteard Tuibear), while three others were from the neighbouring county of Meath (Seán Mac Solaidh, Seán Ó Baotháin and Gearóid Mac Con Midhe). Although O'Rahilly's editorial notes mostly confine themselves to identifying the place of origin of the scholars listed, he does draw attention to the presence of Irish in the capital. For instance, the reference to Risteard Tuibear prompts him to observe: "It is remarkable, as showing how Irish was still spoken almost to the outskirts of

\footnotetext{
${ }^{3}$ Later Éamonn is dismayed to hear that the man of the house is in Killman, before being told that this is merely the place known in Irish as Cill Mhana. Similarly, kill more corresponding to Irish Cill Mhorr, is introduced in the same vein of rather basic cross-linguistic humour, which rests on the fact that the Irish place-name element Cill "church, grave-yard" sounds very like English kill.
} 
Dublin city, to find that such a competent scribe as Risteard Tuibear was a native of Fingal. In 1717 Tuibear resided in Baile Mhistéil, near Mulhuddart, in the parish of Castleknock . . . and this may have been his birthplace" (O’Rahilly 1912-13: 162).

Twenty-six verses long, this poem has an average of one scholar per quatrain. Despite the (admittedly weak) constraints of metre, ${ }^{4}$ many of the scholars are named in the normal way, i.e. by their first name followed by their surname. The various permutations used may be set out as follows:

First name + surname together (7)

Seaán Ua Neachtuin

Uilliam Ua Loingsigh

Aodh Mac Gabhráin

Aodh Mhac Curtaín

Cathal Ó Conchubhair

Aodh Ó Dáladh

Aodh Ua Cobhthaigh

First name + adjective $(s) /$ phrase + surname $(5)$

Proinnsias ... Walseach

Peadar ... Ó Muireagán

Muiris ... Ó Nuabha

Stiophán ... Maolcraoibhe

Gearóid . . . Mac na Midhe

First name only (1)

Éad[h]monn

On the other hand, this order is equally frequently reversed:

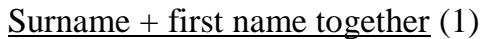

Ó Súilleabháin, Seaán

$\underline{\text { Surname }+ \text { adjective(s) } / \text { phrase }+ \text { first name }}$ (12)

Mac Aodhagáin ... Pól

O Duinín ... T(h)adhg

Ó Hisleanán ... Cathal

An Solamh ... . Seaán

Ó Baothán ... Seaán

${ }^{4} \mathrm{O}$ 'Rahilly is scathing in his criticism of Tadhg's efforts at reproducing the structure of traditional metre, saying that the "degradation of the chief classic metre could hardly have been carried further" and the fact "That even a learned and well-read writer like Tadhg Ó Neachtain could write Deví in this fashion, shows how unintelligible the syllabic metrical system had already become" (O'Rahilly 1912-13: 157). 
Ó Luinín . . . Cathal

Tiobrach . . . Roisteard

Anluain ... Uailintín

Ó Conchubhair ... Diarmuid

Ó Fearghail ... Séamus

Fearghus ... Eóin

Maolm[h]uaidh ... Aodh

(O’Rahilly 1912-13)

A brief word about the content of the first few stanzas of this poem may be in order at this point. Following the initial, introductory verse, in which Tadhg proclaims his intention to set out the names of the leading scholars of Irish to be found in Dublin during his time, three other stanzas follow, which give pride of place to three priests: Pól Mac Aodhagáin, a particularly close friend of the family, Proinnsias Walseach, whom he celebrates as a lexicographer (oide-fhoclóir Éireann 'the dictionary-master of Ireland') and Peadar Ó Muireagán. It is only then that Tadhg introduces the verse praising his own father, Seán. This he does eloquently, calling him niamh na scol 'the jewel of the school(s)':

Seaán Ua Neachtuin, niamh na scol, seanóir ársaigh a chrích Connacht, ughdar fir-ghlic an Ghleacuidh Luinn 's mórán staradh oile dá shamhail.

(O’Rahilly 1912-13: 158)

Seán Ua Neachtain, jewel of the schools, the senior elder from the land of Connacht, the really clever author of An Gleacaí Lonn and many other tales of its kind.

Thus Tadhg takes the opportunity to mention just one of Seán's many compositions, viz. An Gleacai Lonn, which refers to the adventure tale also known as An Gleacai Géaglonnach, in which the hero of the same name is the king of Greece's son. On the other hand, following Seán's death a year later, Tadhg composed an elegy in which many of his father's compositions and translations are specifically alluded to. However, in this elegy the title of the tale just mentioned is cited even more cryptically as An Láidir Lonnach Géag, probably for metrical reasons, as the metre of the stanza in question required ' $e$ ' in that position, thus necessitating the inversion of the usual order of the two elements in the compound Géaglonnach.

Thus, the freshness of the Ó Neachtain approach to scholarship and creative literature can be observed in various ways. First, we have poetry with playful sensibility between the sexes in Rachainn fó' $n$ gcoill leat, which would 
seem to be a development by Seán of earlier, more traditional themes. Second, we have prose (e.g. Stair Éamuinn Uí Chléire) - and indeed poetry elsewhere - with a penchant for the burlesque and a tendency to linguistic excess, as Seán re-invigorates traditional genres. Third, the poem beginning Sloinfead scothadh na Gaoidhilge grinn by Tadhg is a celebration of Dublin's role in an Ireland-wide listing of scholars and their qualities, both professional and human. This interest in contemporary listing is indicative of a modern approach, and, as mentioned already, is in fact one of the hallmarks of Tadhg's works. It is important to note that the concept of a circle is not the creation of O'Rahilly as editor, but rather that of Tadhg as poet. The word most frequently used by Tadhg in the poem to refer to the scholarly group itself is crobha(i)ng, which originally meant 'cluster, bunch (of nuts, fruit, etc.)', but which according to the Royal Irish Academy's Dictionary of the Irish Language occurred more frequently in the transferred sense of 'family, race, kindred etc. in laudatory sense'. The form of the word used is actually cro $(d h)$ bhuinn (there are four examples in all, at lines 36, 62, 76, 100) (Quin 1913-75, s.v. croba(i)ng). Other words employed to refer to the group are lucht 'people, class of persons, category (nearly always with defining gen. or clause)' (line 3), mórdháil 'a great assembly, a general assembly (often of a legislative or judicial meeting)' (line 40), comhdháil 'meeting, tryst, assembly, conference' (line 52) and comhthionól 'act of collecting together, assembling; gathering; collection, assembly' (line 70), each of which occurs just once (see Quin 191375 , s.vv. $)^{5}$

However, it was only with the publication of Robin Flower's Catalogue of Irish Manuscripts in the British Museum, Volume II, in 1926 that the extent of the work of the Ó Neachtains and their collaborators could really have been said to have been brought to the attention of scholars, for Flower included a valuable overall synopsis of their lives and work in his introductions to Egerton manuscripts 139 and 194 (Flower 1992 [1926]: 88-90, 98-101). Flower drew attention to the significance of another list, indeed, another kind of list to be found in one of these manuscripts, noting: "In Eg. 198, f. 2 he [viz. Tadhg] has entered a list of family obits, those down to 1715 being entered at one time, the others added as they occurred" (Flower 1992 [1926]: 98, re Eg. 194). This is to be found in Egerton 198 as follows: ${ }^{6}$

1706/7 feab: 5. ar maidin ag an seacht fuair Una nui bhruin bean seaain ui neachtuin, mathair thaidhg bás.

\footnotetext{
${ }^{5}$ On a point of technicality, one may note that four of the 26 scholars listed are actually named in a series of four stanzas, which were added to the original poem proper. The Munster scribe, Seán Ó Héidéin [John Heyden], is mentioned in yet another additional verse.

${ }^{6}$ Flower's text has been collated with the manuscript by the author.
} 
1710 marta 30: ar maidin diardaoin timchioll an an [sic] seacht, fuair lucas dearbhbhrathair taidhg thuas bás.

1714 abr: 12. idir an haon ndeag. 7 an dó deag, fuair cáit nui ceóiris bean thaidhg ui neachtuin bás.

1714 oct: 12 fuair sean beag mhac taidhg ui neachtuin bás

1715 nov. $\left[9^{b r}\right] .26$ do baiste an naoighin amhuil babóige bige padruic mhac taidhg ui neachtun, 7 fuair bas

1715. 29 nov. [9 $9^{b r}$ fuair Máire nui comáin bean thaidhg tsuas bás

1718. 4. Iún fuair cáit nui comáin dearbhshiúr mháire bás

1720 ab: 16: do fuair tomás mhac cana bás

1725 nov. $\left[9^{\text {br }}\right.$. 15. do fuair Seorsa Ó Reachtagáin bás

1733 Athbraon in .11. fuair Máire nui Reachtagan bean taidhg shuas ba_

1728 Mart in 9 la fuair seaan athair taidhg ui neachtuin bás

1733 nov. $^{b} 3$ do posa in tadhg suas re isebel ní laithrín

1742 mart 25 hadhluiceadh Anna nui Neachtuin deirbhshiuir thaidhg

1745 [1744?] Juil 23 fuair isebel nui larrach bean thaidhg shuas bás

1749 ausguit [ausguid?] an 5. ${ }^{\text {ughadh }}$ la rugad sisilia búrc

1706/7 February 5. In the morning at seven Úna Ní Bhroin, wife of Seán Ó Neachtain, mother of Tadhg, died.

1710 March 30. On Thursday morning about seven, Lúcás brother of the above Tadhg, died.

1714 April 12. Between eleven and twelve Cáit Nic Fheoiris, wife of Tadhg

Ó Neachtain, died.

1714 October 12. Little Sean, son of Tadhg Ó Neachtain, died.

1715 November 26. The doll-like child baby, Pádraig son of Tadhg Ó

Neachtain, was baptised and died.

1715. 29 November. Máire Ní Chomáin, wife of the above Tadhg, died.

1718. 4 June. Cáit Ní Chomáin, sister of Máire, died.

1720 April 16. Tomás Mhac Cana died.

1725 November 15. Seorsa Ó Reachtagáin died.

1733 April the 11. Máire Ní Reachtagáin, wife of the above Tadhg, died.

1728 March the 9. The day that Seán, father of Tadhg Ó Neachtain, died.

1733 November 3. The above Tadhg married Isebel Ní Láithrín.

1742 March 25. Anna Ní Neachtain, sister of Tadhg, was buried.

1745 [1744?] July 23. Isebel Ní Lárrach [Láithrín], wife of the above Tadhg, died.

1749 August the $5^{\text {th }}$. The day Sisilia Búrc was born.

\section{Journey to Spain}

Two contributions by Tomás Ó Cléirigh in the first volume of the journal Éigse (1939-40) cast interesting light on the home-life of the Ó Neachtain family, but strangely did not generate any wider scholarly interest at the time. These were entitled 'Leaves from a Dublin Manuscript' (Éigse 1, 196-209) and 'A Student's Voyage (Ó Neachtain)' (Éigse 1, 103-15). The second of the articles contains a poem by Tadhg, who found it hard to bear the departure of 
his son, Peadar, to enter the Jesuit Irish College in Salamanca, Spain, in May 1728. This prompted him to compose Ochlán Thaidhg Uí Neachtain ar ndul don Spāinn dā mhac Peadar, 'Tadhg Ó Neachtain's Lament on the departure of his son Peadar for Spain'. Tadhg took the opportunity to detail Peadar's early life, beginning with his birth on 29 June 1709, his baptism, his early schooling overseen by his grandfather Seán and by Tadhg himself. The poem names the priest who baptised Peadar, along with his godparents and his many teachers. It was from his grandfather, Seán, that Peadar learned his first letters and grammar, while Tadhg himself taught him music and writing in Irish. Maolradh Ó Broin S.J. and Aodh Ua Conaill taught him humanities and the art of poetry, respectively, while his mathematics teacher was Gearóid Ua Réadhmuin. Rev. Eoin Harold taught him logic. In 1728 Peadar left Dublin by boat, travelling first to Wicklow and then on to Cork, from where he wrote to his father. An anxious six weeks wait followed before a second letter reached Tadhg, announcing Peadar's safe arrival when the ship made harbour in Portugal, after a stormy eleven days at sea. This dangerous journey was followed by a long and expensive sojourn before Peadar was at last able to make his way to Santiago in Galicia, and then on to the Irish College in Salamanca with its learning and true religion. The final verse of Tadhg's poem reads:

Dul 'n-a dháil o bhus deacair dhamh, innlim a gcroidhe is a gcumann seacht gcéad déag fidhche 'sa hocht míle míle biothbhuan beannocht.

(Ó Cléirigh 1939-40a: 103-15)

As it will be difficult for me to go to meet him,

I arrange in heart and in love in seventeen hundred and twenty-eight a thousand thousand everlasting blessings.

Peadar, evidently, lost no time settling into life in the country, as he signed himself Pedro Ignacio O Nachgten in a customary petition to the King of Spain, dated 16 February 1729.

\section{Book lists}

In an article focusing on traditional material, appositely entitled 'Tadhg Ó Neachtuin: A Man of Lists', Emma Nic Cárthaigh has already adverted to Tadhg Ó Neachtain's fondness for tabulation. Presenting a considerable body of evidence on Tadhg's alphabetical listing of place-names and genealogies from Séathrún Céitinn's Foras Feasa ar Eirinn in particular, she summarises the overall situation well, observing: 
At this point, it seems safe to assume that Tadhg Ó Neachtuin was given to making lists of various kind and lengths, on varying subjects, and with varying levels of ambition. His tendency to rationalise the material he came across in this manner is remarkable and characteristic and the mark of this tendency is clearly to be seen on the list of place-names and following miscellanea below . . . it seems clear that Ó Neachtuin was a scribe interested in clarity, the noting down of detail and the listing of material, whether such a practice was originally meant as an aid to himself alone or to others as well.

(Nic Cárthaigh 2004: 213)

Important as the alphabetic listing itself is, the consistent ordering of further information such as the county and barony in which the place is situated is also significant.

(Nic Cárthaigh 2004: 208-9)

Other important compositions by Tadhg show the manner and variety of Tadhg's approaches. In the elegy on the death of his father, already mentioned, Tadhg took the opportunity to list many of his most important works:

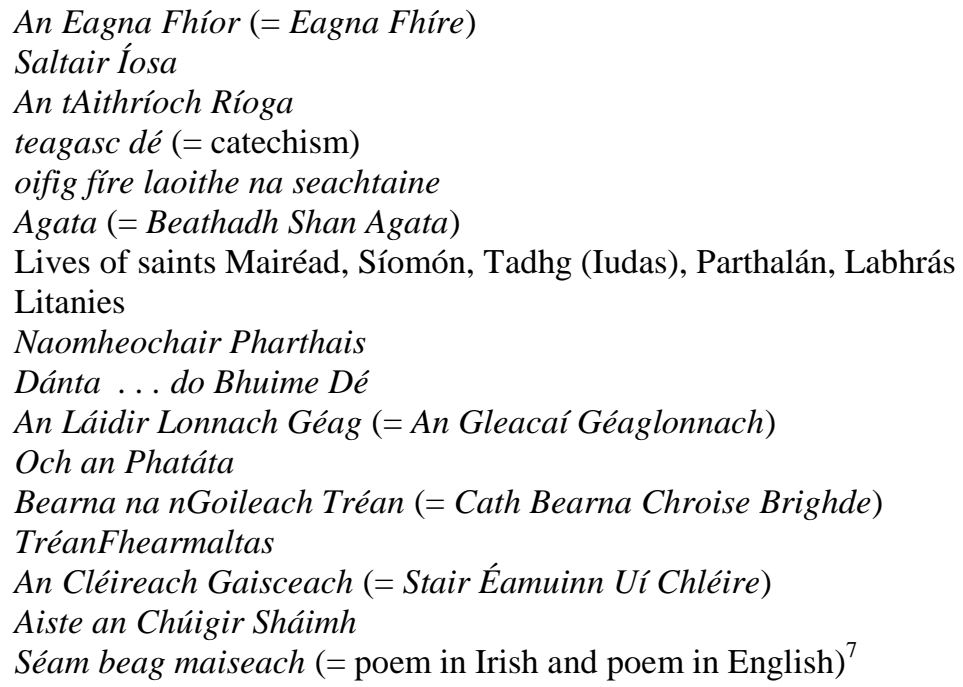

This versified approach in Irish, can be contrasted with later lists, where Tadhg kept track of books and manuscripts he had lent to his friends and acquaintances:

\footnotetext{
${ }^{7}$ Ó Háinle 1983, with the more usual versions of the titles set alongside those which occur in the poem.
} 
1737 the History of Scotland to

Mr. fitzgerald

the old Irish quarto to Dr. Fergus

the bravery of the Irish Mr. Strong

fer maltas to Mr Woodman

tuireadh na heirenn to Mr. heiden and Eadmonn Ua Cleire.

The books out abroad

Forsith has Clarindon (= Edward Hyde, Earl of Clarendon, The History of the rebellion and civil wars in Ireland (London 1720))

Oliver french a virgill $\&$ the hind and pant[h]er (= long poem by John Dryden (1687))

The man on the glib, Malairt an ghreimisg

. . . John hedin has the Irish Survey

Brother Tom the Garden of health crithar

Meala eochir pharthais (= Eochair Pharthais, prayer book)

Stephen Rice an English Metamorphoses has farmaltas

and the book

Mr. Fitzgerald the Painter, the books of

Cantons

Mr. Plunkett in st. francis street

Hugh Curtains writing 3 biorghuithe

Mrs. Henery Pierce the turkish spy

Doctor fergus has the Lilly and the

cathologue of Irish saints in Irish

Richard tiper has desiderius in

English the glacky and book of law

${ }_{7}$ formaltas

Hanlon has the book of law and St.

Collams Amrad

Roe in Leixlip the three shafts of death

Mr. Rice has Newbys 2 books .i. glecuidh

geglonnach

(1736 Mr. Tiper has naor imthecht chuigir (= Imeacht an Chúigir),

ghlecuidh (= An Gleacaí Géaglonnach), lebhar na recht 7 lebhar eile

Archy Mullan has the Christian directory. ${ }^{8}$

${ }^{8}$ See Harrison 1988: 39-40, Harrison 1999: 46-8, and Ó Háinle 2005: 63-4 for the text and clarifications of the rather cryptic versions of the titles cited. 


\section{Conclusion}

The next steps to be taken by research on this aspect of the work of the Ó Neachtains might well include analysis of

- The variant versions of tale titles to be found in different contexts in their manuscripts, e.g. when constrained by verse, as opposed to being cited in prose lists, including whether the poetic or pragmatic-cuminformation aspect is being emphasised;

- The relative importance attached to the various methods of ordering, whether alphabetical, chronological or thematic;

- The proportionate attention given to the copying of traditional listings such as genealogies, in contrast with both contemporary public sphere listings and domestic lists of significant family dates;

- The choice of linguistic medium, whether Irish or English;

- The choice of prose or poetry as literary medium, and the relationship of this to the nature of the material in question (i.e. whether traditional or contemporary, the particular genre in question);

- The extent and nature of the influence of editorial practices in printed books, e.g. the listing of contents to be found in a particular text.

Ultimately, one would wish to set an appreciation of the listing, enumerating, recording and tabulating engaged in by Tadhg Ó Neachtain, in particular, alongside our understanding of his treatment of related areas, such as Irish and world geography, Irish and world history, and contemporary current affairs. This research would help us to deepen our understanding of the nature of the worldview held by him, his father Seán, and their circle of scholarly friends as they and an urban Gaelic Ireland interacted with modernity in early eighteenthcentury Dublin.

University College Dublin, Ireland

\section{References}

Eco, U., 2009, The Infinity of Lists: From Homer to Joyce, London.

Flower, R., 1992, Catalogue of Irish Manuscripts in the British Library [formerly British Museum], Vol. II (1926), Dublin.

Harrison, A., 1988, Ag Cruinniú Meala: Anthony Raymond (1675-1726), Ministéir Protastúnach, agus Léann na Gaeilge $i$ mBaile Átha Cliath [Gathering Honey: Anthony Raymond (1675-1726), a Protestant Minister and Irish Learning in Dublin], Baile Átha Cliath. 
Harrison, A., 1999, The Dean's Friend: Anthony Raymond 1675-1726, Jonathan Swift and the Irish Language, Dublin.

Mac Mathúna, L., 2010, 'Snapshot or Signpost? The Role of English in Tadhg Ó Neachtain's Early Eighteenth-Century Manuscripts', in: Fomin, M., Jarniewicz J., Stalmaszczyk, P., eds., Dimensions and Categories of Celticity: Studies in Literature and Culture. Studia Celto-Slavica 5, Lódź, 29-46.

Ní Fhaircheallaigh, Ú., (ed.), 1911, Filidheacht Sheagháin Uí Neachtain [The Poetry of Seaghán Ó Neachtain], Baile Átha Cliath.

Nic Cárthaigh, E., 2004, 'Tadhg Ó Neachtuin: A Man of Lists', in: Carey, J., Herbert, M., Murray, K., eds., Cín Chille Cúile [The Book of Cill Chúile], Aberystwyth.

Ó Buachalla, B., 1996, Aisling Ghéar: Na Stíobhartaigh agus an tAos Léinn 1603-1788 [A Keen Vision: The Stuarts and the Learned Class 1603-1788], Baile Átha Cliath.

Ó Cléirigh, T., 1939-40a, ‘A Student's Voyage (Ó Neachtain)', Éigse 1, 10315.

Ó Cléirigh, T., 1939-40b, 'Leaves from a Dublin Manuscript', Éigse 1, 196209.

Ó Háinle, C., 1978, 'An tÚrscéal nár Tháinig' [The Novel that did not Come], in: Promhadh Pinn [Probatio Pennae], Má Muad, 74-98.

Ó Háinle, C., 1983, 'Ar Bhás Sheáin Uí Neachtain' [On the Death of Seán Ó Neachtain], Éigse 19, 384-94.

Ó Háinle, C. G., 2004, 'The Novel Frustrated: Developments in $17^{\text {th }}$ - to $19^{\text {th }}$ century Fiction in Irish', in: Ó Háinle, C. G., Meek, D. E., eds., Unity in Diversity: Studies in Irish and Scottish Gaelic Language, Literature and History, Dublin, 125-51.

Ó Háinle, C., 2005, 'Seán agus Tadhg Ó Neachtain: Cleamhnas agus Gaol' [Seán and Tadhg Ó Neachtain: Marriage and Blood Relationship], Éigse 35, 53-70.

Ó Neachtain, E., (ed.), 1918, Stair Éamuinn Uí Chléire de réir Sheáin Uí Neachtain [The History of Éamonn Ó Cléirigh according to Seán Ó Neachtain], [Dublin].

O'Rahilly, T. F., 1912-13, 'Irish Scholars in Dublin in the Early Eighteenth Century', Gadelica 1, 156-62, 302-3.

Quin, E. G., et al., eds., 1913-75, Contributions to the Dictionary of the Irish Language, Dublin. 